\title{
Pereskia bleo Leaves Extract Induces Cell Death via Cell Cycle Arrest and Apoptosis in Cervical Cancer Cells HeLa
}

Siti Farhanah Mohd-Salleh, Wan Suriyani Wan-Ibrahim \& Norzila Ismail

To cite this article: Siti Farhanah Mohd-Salleh, Wan Suriyani Wan-Ibrahim \& Norzila Ismail (2019):

Pereskia bleo Leaves Extract Induces Cell Death via Cell Cycle Arrest and Apoptosis in Cervical Cancer Cells HeLa, Nutrition and Cancer, DOI: 10.1080/01635581.2019.1654530

To link to this article: https://doi.org/10.1080/01635581.2019.1654530

Published online: 21 Aug 2019.

Submit your article to this journal $\sqsubset$

Q View related articles $\square$

View Crossmark data $\subset$ 


\title{
Pereskia bleo Leaves Extract Induces Cell Death via Cell Cycle Arrest and Apoptosis in Cervical Cancer Cells HeLa
}

\author{
Siti Farhanah Mohd-Salleh (D), Wan Suriyani Wan-Ibrahim (D), and Norzila Ismail \\ Department of Pharmacology, School of Medical Sciences, Universiti Sains Malaysia, Kelantan, Malaysia
}

\begin{abstract}
Introduction: Pereskia bleo is a leafy and edible plant, locally known as "Pokok Jarum Tujuh Bilah" which has anticancer properties. This study purposed to determine the cytotoxic effects of $P$. bleo leaves extracts on several well-known cancer cells and elucidate its underlying mechanism in inducing cell death.

Methods: Cytotoxic activity on selected cell lines was determined using MTT assay. Mechanism of cell death was investigated through cell cycle and Annexin $\mathrm{V}$ assay. Expression of apoptotic proteins was measured by flow cytometry method.

Results: Ethyl acetate extract of $P$. bleo leaves (PBEA) appeared to have the strongest $I_{50}$ value $(14.37 \pm 8.40 \mu \mathrm{g} / \mathrm{ml})$ and most active against HeLa cells was further studied for apoptosis. The cell cycle investigation by flow cytometry evidenced the increment of PBEA treated HeLa cells in $G_{0} / G_{1}$ phase and apoptotic event was detected in Annexin $V$ assay. Analysis of apoptotic protein showed pro-apoptotic proteins (Bax, p53 and caspase 3) were triggered where as anti-apoptotic protein $\mathrm{Bcl}-2$ was suppressed in treated HeLa cells.

Conclusions: Our findings demonstrated that PBEA treatment induced cell death in HeLa cells by $\mathrm{p} 53$-mediated mechanism through arresting cell cycle at $\mathrm{G}_{0} / \mathrm{G}_{1}$ phase and mitochondrial-mediated pathway with involvement of pro-apoptotic proteins, anti-apoptotic protein, and caspase 3.
\end{abstract}

\section{ARTICLE HISTORY}

Received 13 June 2019

Accepted 6 August 2019

\section{Introduction}

Cancer is a condition that occurs when abnormal cells in the body proliferate uncontrollably causing normal cells to die (1). To date, cancer remains the primary cause of death in humans worldwide in spite of the advancement in tools for its diagnosis, treatment, and prevention (2). It remains a global public health issue as its mortality and morbidity rate are predicted to increase every year (3). Conclusive cancer treatment is important and urgently needed for future management of the disease. Conventional cancer treatments such as surgery, chemotherapy, and radiotherapy, even though proven to be effective, remains unsatisfactory in some types of cancer such as detrimental side effects, cancer prevalence, and decline of general health in cancer patients (4). Thus, the discovery of novel potent anticancer agents for cancer treatment will always be in demand.

Apoptosis, or programed cell death, is critical in eliminating cancer cells via the stimulation by certain chemicals $(5,6)$. Therefore, apoptosis activation has been pointed out as the main strategy in inhibiting the proliferation of cancer cells (7). Recently, the application of natural products including medicinal plants has caught the attention of oncologists for alternative treatment of cancer. Both plants and their products including crude extracts and pure compounds are recognized as pro-apoptotic agents due to their various mechanism of actions and their side effects are often insignificant $(8,9)$. Nevertheless, in traditional practice, plants are often consumed raw or in the form of crude extracts for medication purposes. Studies have reported the efficacy of plant crude extracts compared to single compounds in cancer research $(10,11)$. Besides that, drugs that are derived from plants are often accessible, inexpensive, and safe with minimal side effects (12). Furthermore, synergistic actions from various phytochemicals in the crude extracts may be the reason behind the healing potential of the plants (13).

Pereskia bleo belongs to the family Cactaceae (14), a plant well known for its medicinal properties. In the Malay language, P. bleo is called "Pokok Jarum Tujuh

CONTACT Norzila Ismail norzila_ismail@usm.my D Department of Pharmacology, School of Medical Sciences, Universiti Sains Malaysia, 16150 Kubang Kerian, Kelantan, Malaysia.

Color versions of one or more of the figures in the article can be found online at www.tandfonline.com/hnuc.

(C) 2019 Taylor \& Francis Group, LLC 
Bilah" while the Chinese calls it "Cak Sing Cam" $(15,16)$. It is a deciduous, undergrowth, tree-like plant with a height ranging from $0.6 \mathrm{~m}$ to $8 \mathrm{~m}$. Its leafy trunk often exists with 5-7 black spines (14). Its flowers are orange-red in color while its leaves are thin, glossy, and succulent with oblong to oblanceolate in shape $(14,17,18)$. This plant is popular in Malaysia as well as China and the leaves are edible usually consumed raw or concocted and brewed to be taken as tea acting as a remedy for hemorrhoid, hypertension, diabetes, infections, headaches, rheumatism, asthma, and for other dietary benefits (19-21). In addition, the locals believe that it can also be used for cancer prevention $(20,22,23)$. Earlier studies have reported that $P$. bleo biological activities include anticancer, antitumor, antirheumatic, anti-ulcer, anti-inflammatory, anti-oxidant, and antimicrobial $(16,22,24)$.

Several in vitro studies have shown that the leaves extracts from $P$. bleo leaves demonstrated cytotoxic effects in various cancer cell lines such as human hormone dependent breast carcinoma cell line (MCF7), human lung carcinoma cell line (A549), human colon carcinoma cell line (HCT 116), human nasopharyngeal epidermoid carcinoma cell line (KB), and human cervical carcinoma cell line (CasKi) $(20,22)$. However, there is a lack of information regarding its effects on other common cancer cell lines. Therefore, the current study aims to explore the cytotoxic response of $P$. bleo leaves extracts on HeLa, MDA-MB-231, HepG2, and SW480 cell lines. To understand the mechanism of cell death in this study, further investigation on apoptosis induction was conducted to identify the most significant cytotoxic activity among the cell lines.

\section{Materials and Methods}

\section{Sample Collection}

The leaves of $P$. bleo were collected from Kota Bharu, Kelantan and verified by Dr. Rahmad Zakaria. A voucher specimen (11575) was submitted to the herbarium at the School of Biology, Universiti Sains Malaysia (USM), Penang.

\section{Preparation of the Extracts}

The leaves of $P$. bleo were rinsed thoroughly with water before being subjected to oven-drying at $50{ }^{\circ} \mathrm{C}$ and then processed into powder form. Twenty grams of powdered leaves were extracted by using n-hexane, ethyl acetate, and methanol by using Soxhlet apparatus. The extracts were then concentrated via the rotary evaporator. Aqueous extract was prepared by decoction method where $10 \mathrm{~g}$ of the sample was boiled in $450 \mathrm{ml}$ water at $50^{\circ} \mathrm{C}$ until the water was reduced to one-third of its initial volume then proceed filtration with Whatman filter paper no. 1. After that, the extract was freeze-dried. All the extracts were then dissolved in dimethylsulfoxide (DMSO; Merck) and later diluted to several working concentrations.

\section{Cell Lines and Cell Culture}

Cancer cell lines namely cervical (HeLa), breast (MDA-MB-231), colon (SW480), liver (HepG2), and normal mouse fibroblast cell line (NIH 3T3) were purchased from ATCC. A complete medium containing Dulbecco's Modified Eagle's Medium (DMEM; Gibco), $10 \%$ of fetal bovine serum (FBS; Gibco), $1 \%$ of penicillin-streptomycin (Gibco) under a humidified air atmosphere containing $5 \% \mathrm{CO}_{2}$ at $37^{\circ} \mathrm{C}$ were used in the culture of the cell lines.

\section{Cytotoxic Activity Assay}

An assay using 3-[4,5-dimethyl thiazol-2-yl] 2,5diphenyl tetra-zolium bromide (MTT; Merck) were carried out to measure the cytotoxicity activity of $P$. bleo extracts. The cells were seeded in 96-well flat bottomed plates (Eppendorf) at a density of $5 \times 10^{4}$ cells per well in a final volume of $100 \mu \mathrm{l} /$ well. After $24 \mathrm{~h}$ incubation at $37^{\circ} \mathrm{C}$ with $5 \% \mathrm{CO}_{2}$, the cells were treated with $\mathrm{n}$-hexane, ethyl acetate, methanol, and aqueous extracts at different concentrations $(0.3-99 \mu \mathrm{g} / \mathrm{ml})$. After $72 \mathrm{~h}, 50 \mu \mathrm{l}$ of MTT solution $(2 \mathrm{mg} / \mathrm{ml})$ were added to each well and further incubated for $4 \mathrm{~h}$ at $37^{\circ} \mathrm{C}$. Then, $200 \mu \mathrm{l}$ of DMSO was added to each well to dissolve the MTT crystals and absorbance was taken at $570 \mathrm{~nm}$ using an enzymelinked immunosorbent assay (ELISA) plate reader. Each experiment was performed in triplicates. $\mathrm{IC}_{50}$ values of the treated cancer and normal cells were determined as formula below to determine the cytotoxicity effect of all extracts.

Percentage of cell viability $(\%)=$ (Absorbance of treated cells/Absorbance of control) $\times 100 \%$

Since ethyl acetate extract of $P$. bleo leaves (PBEA) showed the strongest $\mathrm{IC}_{50}$ value against most active cancer cells HeLa, only PBEA and HeLa cells were used further in the study.

\section{Cell Cycle Assay}

Flow cytometry was used to evaluate the changes in cell cycle distribution of HeLa cells induced by PBEA. 
Table 1. $I C_{50}$ values of $P$. bleo leaves extracts on selected cancer and normal cell lines after $72 \mathrm{~h}$ incubation period.

\begin{tabular}{|c|c|c|c|c|c|}
\hline \multirow[b]{2}{*}{ Types of cell lines } & \multicolumn{5}{|c|}{$\mathrm{IC}_{50}$ values $(\mu \mathrm{g} / \mathrm{ml})$} \\
\hline & Hexane extract & Ethyl acetate extract & Methanol extract & Aqueous extract & Tamoxifen \\
\hline HeLa (cervical cancer) & $20.24 \pm 11.69$ & $14.37 \pm 8.40$ & $>99$ & $>99$ & $2.71 \pm 0.88$ \\
\hline MDA-MB-231 (breast cancer) & $43.76 \pm 36.86$ & $41.60 \pm 35.68$ & $>99$ & $>99$ & $2.24 \pm 0.95$ \\
\hline HepG2 (liver cancer) & $>99$ & $>99$ & $>99$ & $>99$ & $3.80 \pm 1.07$ \\
\hline SW480 (colon cancer) & $>99$ & $>99$ & $>99$ & $>99$ & $2.66 \pm 0.22$ \\
\hline NIH/3T3 (normal mouse fibroblast) & $>99$ & $>99$ & $>99$ & $>99$ & $3.78 \pm 1.46$ \\
\hline
\end{tabular}

The $\mathrm{IC}_{50}$ data are the average value of three independent experiments and represented as mean $\pm \mathrm{SD}$.

The cells were treated with PBEA at a concentration of $\mathrm{IC}_{50}$ and incubated at $37^{\circ} \mathrm{C}$ with $5 \% \mathrm{CO}_{2}$ for certain periods $(24 \mathrm{~h}, 48 \mathrm{~h}$, and $72 \mathrm{~h}$ ). After that, the samples were processed using BD Cycletest ${ }^{\mathrm{TM}}$ Plus DNA Kit (BD Bioscience) as per kit's instruction. The cells were resuspended in buffer solution at concentration of $5 \times 10^{5}$ cells per sample. Then, the cells were incubated with trypsin buffer (10 min, room temperature), trypsin inhibitor and RNase buffer $(10 \mathrm{~min}$, room temperature) and lastly cold PI stain solution (10 min, $2{ }^{\circ} \mathrm{C}-8{ }^{\circ} \mathrm{C}$ ) in the dark on ice. After incubation, the samples were analyzed using FACSCANTO II (BD Bioscience). A minimum of 10,000 events was acquired per sample and the data was analyzed by using ModFiT LT 5.0 software.

\section{Annexin V-FITC Assay}

Annexin V-FITC Detection Kit I (BD Bioscience) was used to identify the distribution of early or late apoptosis induced by PBEA towards HeLa cells. The assay was conducted as instructed in manufacture's manual. The cells were later incubated with the $\mathrm{IC}_{50}$ concentration of PBEA for $24 \mathrm{~h}, 48 \mathrm{~h}$, and $72 \mathrm{~h}$ at $37^{\circ} \mathrm{C}$ with $5 \% \mathrm{CO}_{2}$. After that, the cells were washed two times with cold PBS and stained with $5 \mu$ of FITC Annexin $\mathrm{V}$ and $5 \mu \mathrm{l}$ of propium iodide (PI) for $15 \mathrm{~min}$ at room temperature under dark condition. Results for the stained cells were obtained (10,000 events per sample) through FACSCANTO II (BD Bioscience). The data acquired were analyzed by using FlowJo_V10 software. The test was repeated thrice independently.

\section{Apoptosis Proteins Assay}

Expression level of apoptosis proteins Bax, Bcl-2, p53 and caspase- 3 in HeLa cells following treatment with PBEA were determined by the means of flow cytometry. Cells were incubated with the $\mathrm{IC}_{50}$ concentration of PBEA for $24 \mathrm{~h}, 48 \mathrm{~h}$, and $72 \mathrm{~h}$ at $37^{\circ} \mathrm{C}$ with $5 \%$ $\mathrm{CO}_{2}$. The proteins were stained with antibody conjugate according to the manufacturer's protocol. The cells were later harvested and washed with PBS. After that, the cells $\left(1 \times 10^{6}\right.$ cells $)$ were fixed with ice cold
$70 \%$ ethanol for $1 \mathrm{~h}$ at $4{ }^{\circ} \mathrm{C}$. The cells were washed twice after fixation and blocked in $2 \%$ bovine serum albumin for $10 \mathrm{~min}$ at room temperature. After the blocking process, $100 \mu \mathrm{l}$ of cells $\left(1 \times 10^{5}\right.$ cells $)$ were transferred into flow tubes and stained with antibodies: Bax-PE (Santa Cruz), Bcl-2-Alexa Fluor 647 (Santa Cruz), p53-Alexa Fluor 480 (Santa Cruz), and caspase 3-Alexa Fluor 480 (Santa Cruz). Results for 10,000 events per sample were recorded with FACSCANTO II (BD Bioscience). The data were then analyzed using FlowJo_V10 software. The experiment was carried out thrice independently.

\section{Statistical Analysis}

Each data was presented as mean \pm SD. The results were analyzed using repeated measure one-way ANOVA $(P<0.05)$. All statistical analysis were performed with GraphPad Prism 7 software.

\section{Results}

\section{Cytotoxicity of P. bleo Leaves Extracts on Selected Cancer Cell Lines}

The cytotoxicity of $P$. bleo leaves extracts on selected cancer and normal cell lines were determined using MTT assay. The control treatment in this study was Tamoxifen. P. bleo that were extracted using ethyl acetate (PBEA) showed higher cytotoxic effects on HeLa $(14.37 \pm 8.40 \mu \mathrm{g} / \mathrm{ml})$ and MDA-MB-231 cells compared to hexane (Table 1 ). The cell viability was reduced significantly in a dose and time-dependent manner (Fig. 1). On the other hand, P. bleo extracted with methanol and aqueous leaves extracts showed no cytotoxic effects towards all cell lines, with the maximum cut off concentration at $99 \mu \mathrm{g} / \mathrm{ml}$. In addition, all extracts do not exert cytotoxic effects against normal cell line (NIH/3T3).

\section{Cell Cycle}

The effects of PBEA on cell cycle distribution in HeLa cells were evaluated by flow cytometry method. Cells 
treated with $\mathrm{IC}_{50}$ value of PBEA for $72 \mathrm{~h}$ were analyzed for the distribution of $G_{0} / G_{1}, S$ and $G_{2} / M$ phases of cell cycle (Fig. 2). The results demonstrated that PBEA treatment resulted in a significant accumulation of cells in the $G_{0} / G_{1}$ phase but decreased in $S$ and $\mathrm{G}_{2} / \mathrm{M}$ phases $(P<0.05)$ compared to control. This showed that PBEA induced changes in the cell cycle progression of HeLa cells by causing the arrest of $G_{0} / G_{1}$ phase.

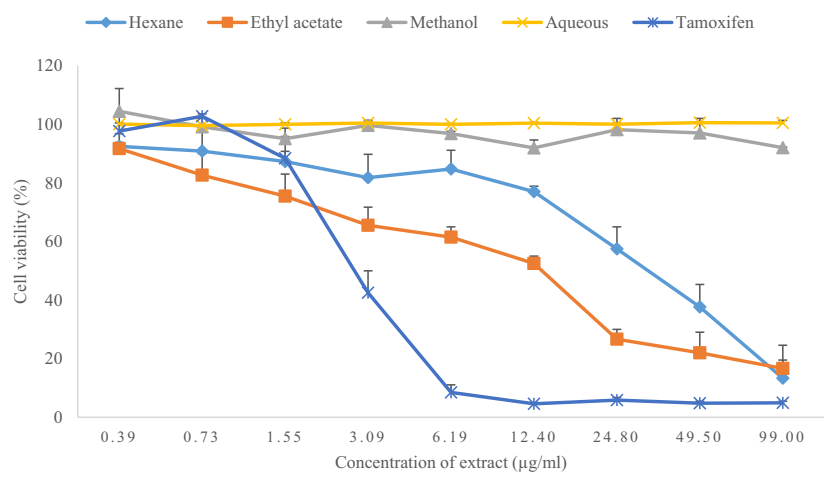

Figure 1. Cytotoxicity of $P$. bleo leaves extracts (hexane, ethyl acetate, methanol, and aqueous) and tamoxifen on HeLa cells treated with different concentrations for $72 \mathrm{~h}$. The data of three independent experiments are represented as mean \pm SD.

\section{Apoptosis}

To identify whether or not the cells underwent apoptosis, control and treated HeLa cells with PBEA were stained with Annexin V and PI to measure the presence of apoptotic cells. The event of apoptosis has occurred in HeLa cells within $72 \mathrm{~h}$ upon treatment with PBEA as per flow cytometric analysis result shown in Fig. 3. The apoptosis rate was significantly different for every incubation period in treated groups compared to control group $(P<0.05)$.

\section{Flow Cytometry of Apoptosis Proteins Expression Levels}

Apoptotic proteins (Bax, Bcl-2, p53, and caspase-3) expression levels in HeLa cells following treatment with $14.37 \pm 8.40 \mu \mathrm{g} / \mathrm{ml}$ of PBEA were assessed by flow cytometry analysis (Fig. 4). PBEA upregulated protein levels of Bax and p53, whereas Bcl-2 was downregulated in a time-dependent manner following the $72 \mathrm{~h}$ treatment period. There were significant differences observed for the expression levels of Bax, p53 and Bcl-2 treated and control cells. Even though there was only a slight upregulation in the expression of

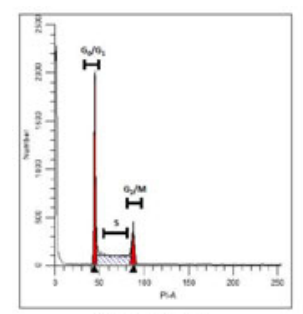

Control

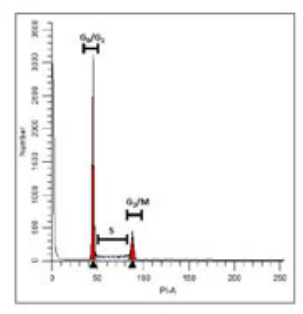

$24 \mathrm{~h}$

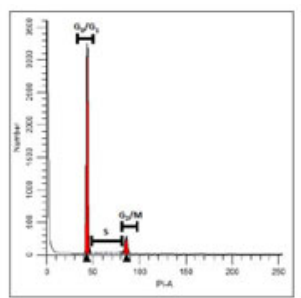

$48 \mathrm{~h}$

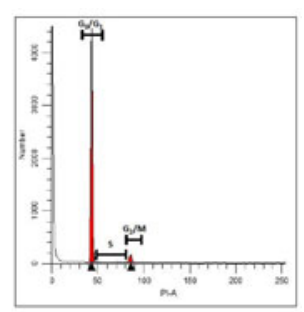

$72 \mathrm{~h}$

(A)
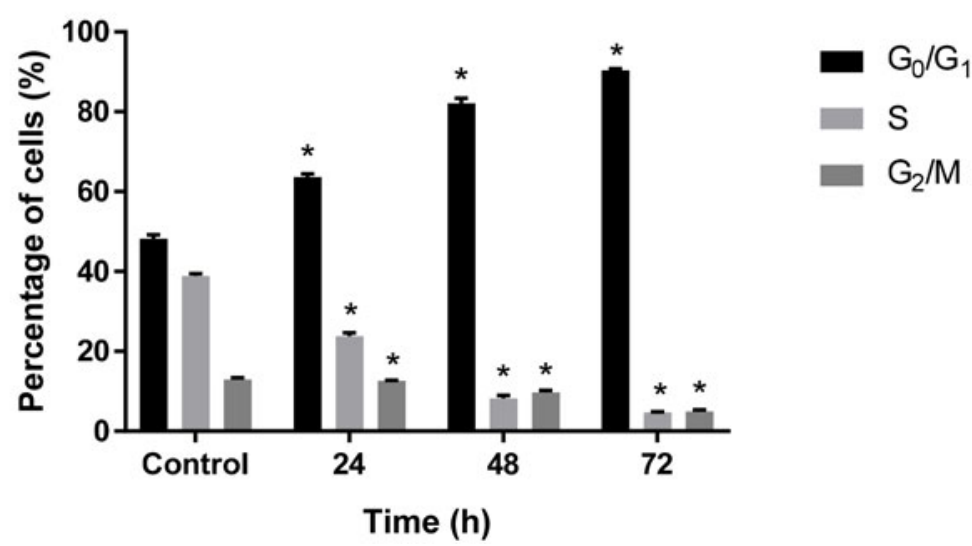

Figure 2. The effects of PBEA on cell cycle of HeLa cells. (A) The flow cytometry histogram shows the DNA content and the corresponding percentage of cell distribution in control and treated HeLa cell for $24 \mathrm{~h}, 48 \mathrm{~h}$, and $72 \mathrm{~h}$. Cell cycle distribution showing accumulation of treated cells in $G_{0} / G_{1}$ phase. (B) The bar columns are represented as mean $\pm S D$ from three independent experiments. ${ }^{*} P<0.05$ when compared with the control group. 


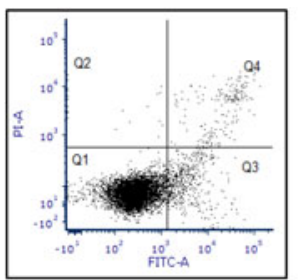

Control

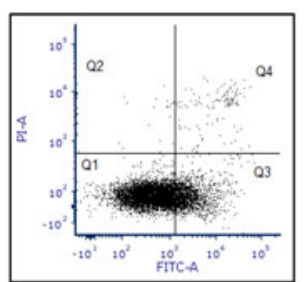

24 h

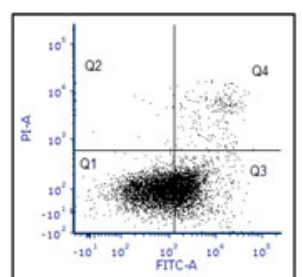

$48 \mathrm{~h}$

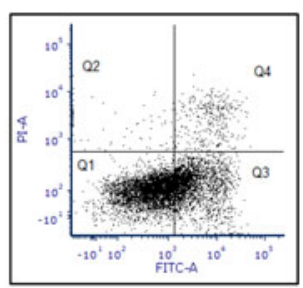

72 h

(A)

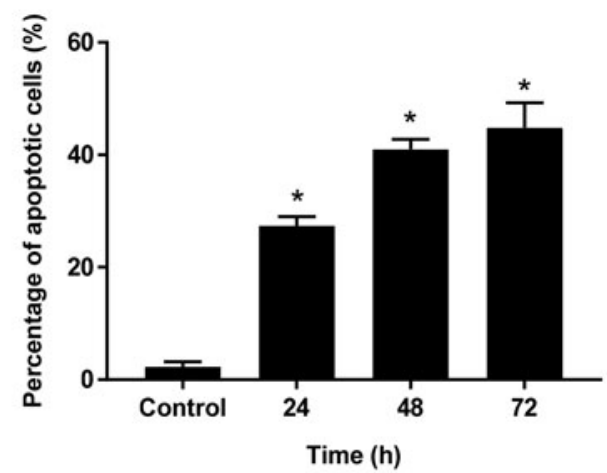

(B)

Figure 3. (A) Distribution of Annexin V-FITC staining dot plots in control and PBEA treated HeLa cells detected by flow cytometry after $24 \mathrm{~h}, 48 \mathrm{~h}$, and $72 \mathrm{~h}$ incubation. Four quadrants represent viable cells (Q1), necrotic cells (Q2), early apoptotic cells (Q3), and late apoptotic cells (Q4). (B) The bar column illustrated the percentage of HeLa cells undergoing apoptosis. The data represent the mean \pm SD of three independent experiments. ${ }^{*} P<0.05$ when compared with the control group.

caspase-3, the results remain significantly different between treated and control cells.

\section{Discussion}

The search for anticancer agents from botanical sources has been gaining popularity worldwide due to their potential in arresting cancer cell proliferation with negligible side effects besides being domestically accessible. At present, a large number of active compounds from natural sources such as herbs and medicinal plants have been isolated and developed as new drugs for cancer treatment (25). P. bleo leaves is one of the important sources of medication and traditionally used to treat various ailments such as hemorrhoid, hypertension, cancer, diabetes, infections, headaches, rheumatism, asthma as well as being consumed for dietary benefits (19-22).

Pharmacology screening of plants is essential in the search for novel and effective drugs with minimal side effects (26). According to the National Cancer Institute (NCI), in vitro cytotoxic activity of crude extract with $\mathrm{IC}_{50}$ value $\leq 20 \mu \mathrm{g} / \mathrm{mL}$ is considered highly cytotoxic (27). The $\mathrm{IC}_{50}$ value of a good anticancer agents should be low to avoid undesirable effects (28). In the present study, PBEA exhibited the highest cytotoxic activity with $\mathrm{IC}_{50}$ value of $14.37 \pm 8.40 \mu \mathrm{g} / \mathrm{ml}$ and selectively against $\mathrm{HeLa}$ cells while no cytotoxicity was observed in normal cells. The ability of the extract to distinguish between normal and malignant cells is a crucial aspect in the development of an anticancer agent (29). The characteristic of PBEA is consistent with this concept hence possess high potential to become an anticancer agent for cervical cancer. PBEA is known to contain several useful phytochemicals such as terpenoids, and phenolic compounds (20,22,30). Various studies have reported that terpenoids and phenols exhibited cytotoxic activity against several cancer cells like colon and liver $(31,32)$. Thus, the presence of these phytochemicals might contribute to the cytotoxic activity of PBEA.

Cell cycle dispersal and induction of apoptosis were tested to determine the mechanism involved in the inhibition of cell growth by PBEA leading to cytotoxicity in HeLa cells. Cell cycle analysis demonstrated that PBEA arrested HeLa cells at $G_{0} / G_{1}$ phase in a time-dependent manner as the accumulation of the cells were noticeable at this stage after $72 \mathrm{~h}$. This finding indicates that PBEA may inhibit the progression of proliferation in HeLa cells at $G_{0} / G_{1}$ phase. During cell division, checkpoints that exist at each phase of 
Control

Bax
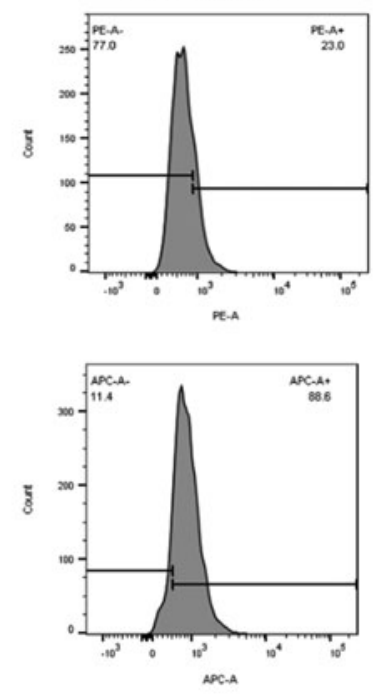

Bcl-2

p53
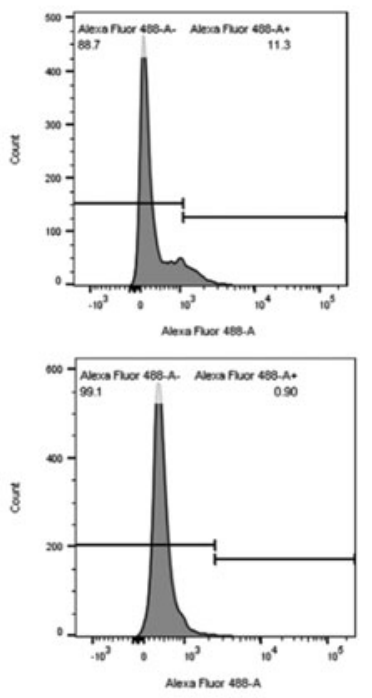

$24 \mathrm{~h}$
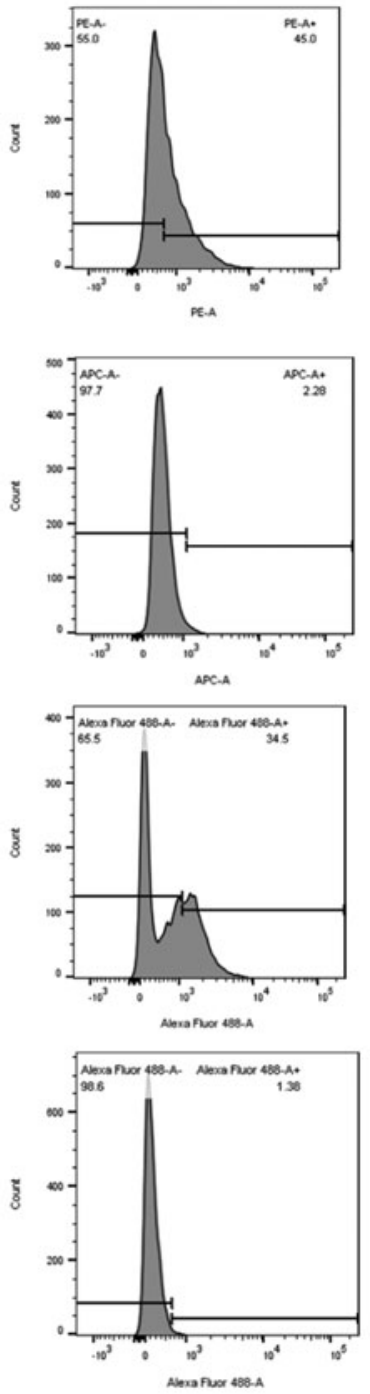

$48 \mathrm{~h}$
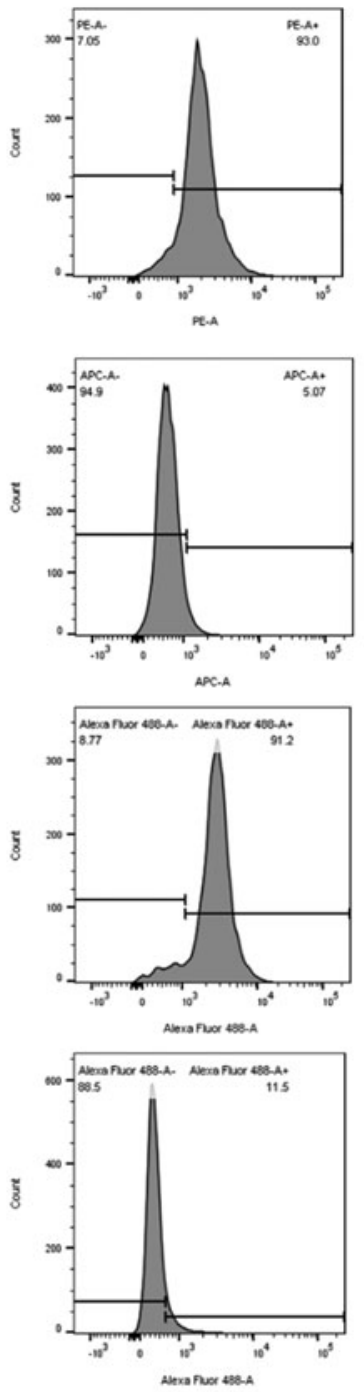

$72 \mathrm{~h}$
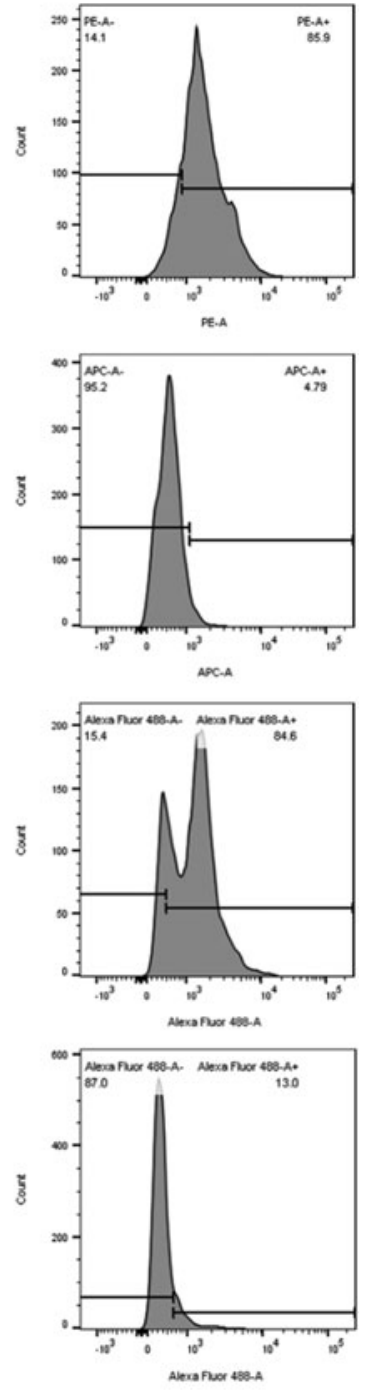

(A)

Figure 4. Flow cytometry analysis of apoptosis proteins expression in HeLa cells induced by PBEA. (A) Histograms of apoptosis protein Bax, Bcl-2, p53, and caspase-3 (cas-3) expression level measured in HeLa cells for control and treated with PBEA after $24 \mathrm{~h}$, $48 \mathrm{~h}$, and $72 \mathrm{~h}$ incubation. (B) The bar columns showed the percentage of apoptosis proteins expression in control and HeLa cells treated with PBEA. PBEA, in a time-dependent manner has significantly upregulated expression of Bax, p53 and caspase-3, whereas $\mathrm{BCl}-2$ was downregulated. The data were shown as mean \pm SD which represent for three independent experiments. $* P<0.05$ when compared with control group.

the cell cycle will identify the potential DNA impairment which allows for cell repair to take place (33). Arresting DNA replication at $G_{0} / G_{1}$ phase can direct the cells either to be repaired or to undergo apoptosis (34-36). This is the synergistic mechanisms for the cytotoxic effects of cytotoxic agents in cancer cells (37).

To confirm the onset of apoptosis following cell cycle arrest, HeLa cells treated with PBEA were stained with Annexin V-FITC and analyzed using flow cytometry. Apoptosis activation in a timedependent manner was observed due to the accumulation of apoptotic cells in both early and late stage of apoptosis. This finding confirmed that HeLa cells had undergone apoptosis as a result of the cytotoxic effects exerted by PBEA.

Apoptosis can be activated via different pathways and controlled by pro-apoptotic and anti-apoptotic proteins. Thus, protein analysis was performed via flow cytometry to further explain the role of apoptotic proteins in apoptosis of HeLa cells induced by PBEA. The findings of this study showed that PBEA stimulated the expression of pro-apoptotic protein Bax and suppressed the anti-apoptotic protein $\mathrm{Bcl}-2$ which 

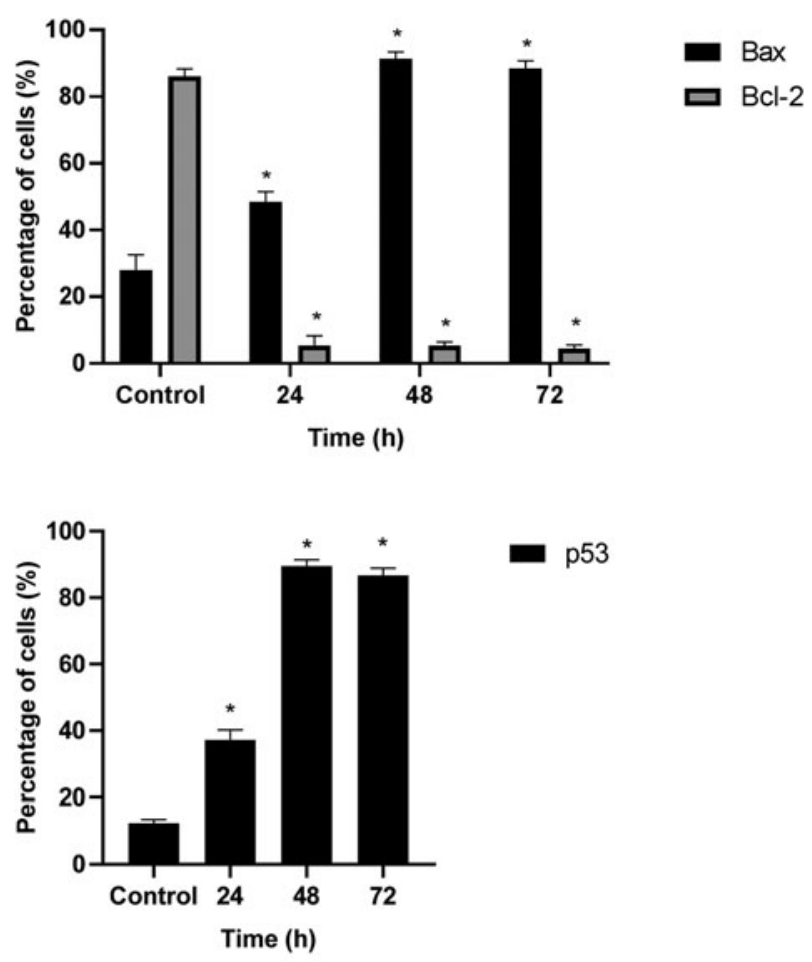

p53

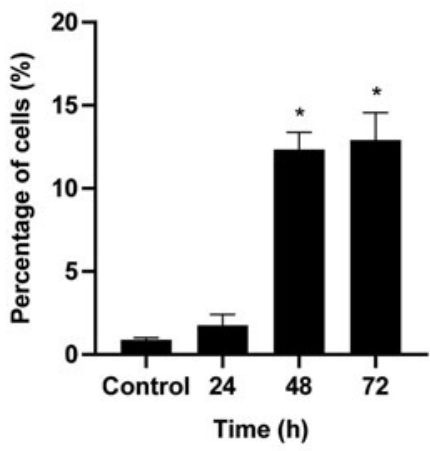

- Caspase 3

(B)

Figure 4. Continued

eventually leads to apoptosis. PBEA acted as an apoptosis inducer, repressing Bcl-2 expression through the increment of p53 level in HeLa cells. This observation is in line with a study by Wang et al. (38) who reported that barberin hydrochloride acted as an efficient apoptotic inducer in HeLa cells. In healthy cells, the tumor suppressor p53 remained at low concentration. p53 protein level will elevate due to various stimuli and regulate apoptotic gene expression (39). It induces apoptosis by suppressing anti-apoptotic proteins such as survivin and $\mathrm{Bcl}-2$. At the same time, pro-apoptotic protein such as Bax is activated thus initiating the caspase cascade $(40,41)$. Activation of pro-apoptotic proteins promoted mitochondrial membrane permeability which stimulates the occurrence of apoptotic cell death (42).
The caspase cascade signaling system is an essential component in the process of apoptosis as it is controlled by various proteins that either promote or inhibit apoptosis (43). In this study, caspase-3 expression level was slightly increased in HeLa cells upon treatment with PBEA. Similar finding was reported in breast carcinoma cell line (T47-D) treated with methanol extract of P. bleo where apoptosis was induced naturally via caspase- 3 and c-myc pathway (15). Thus, activation of caspase-3 through extrinsic or intrinsic pathway initiate the action of other proteins which leads to apoptosis.

\section{Conclusions}

The results of this study clearly demonstrated that PBEA induced apoptosis in cervical cancer HeLa cells 
through $\mathrm{Bax} / \mathrm{Bcl}-2$ signaling pathway with the involvement of caspase-3, while inducing $G_{0} / G_{1}$ phase cycle arrest via $\mathrm{p} 53$-mediated mechanism. Therefore, it can be concluded that $P$. bleo has the potential to become a cancer prevention agent. Further research, particularly in vivo study, should be carried out to provide further evidence of the anticancer properties of this plant.

\section{Disclosure Statement}

Authors have no conflict of interest to declare.

\section{Funding}

This study was funded by Universiti Sains Malaysia under the Short Term Grant Scheme (304/PPSP/6315179).

\section{ORCID}

Siti Farhanah Mohd-Salleh (iD http://orcid.org/0000-00023048-702X

Wan Suriyani Wan-Ibrahim (iD) http://orcid.org/0000-00028538-3447

Norzila Ismail (D) http://orcid.org/0000-0002-1644-1690

\section{References}

1. Zhang F, Shi JJ, Thakur K, Hu F, Zhang JG, et al.: Anti-cancerous potential of polysaccharide fractions extracted from peony seed dreg on various human cancer cell lines via cell cycle arrest and apoptosis. Front Pharmacol 8, 1-13, 2017.

2. Razali FN, Sinniah SK, Hussin H, Zainal Abidin N, and Shuib AS: Tumor suppression effect of Solanum nigrum polysaccharide fraction on breast cancer via immunomodulation. Int J Biol Macromol 92, 185-193, 2016. doi: 10.1016/j.ijbiomac.2016.06.079.

3. Pumiputavon K, Chaowasku T, Saenjum C, Osathanunkul M, Wungsintaweekul B, et al.: Cell cycle arrest and apoptosis induction by methanolic leaves extracts of four Annonaceae plants. BMC Complement Altern Med 17, 1-11, 2017. doi: 10.1186/ s12906-017-1811-3.

4. Schloss J, Colosimo M, and Vitetta L: Herbal medicines and chemotherapy induced peripheral neuropathy (CIPN): a critical literature review. Crit Rev Food Sci Nutr 57, 1107-1118, 2017. doi: 10.1080/ 10408398.2014.889081.

5. Wyllie AH, Bellamy CO, Bubb VJ, Clarke AR, Corbet $\mathrm{S}$, et al.: Apoptosis and carcinogenesis. $\mathrm{Br} \mathrm{J}$ Cancer 80, 34-37, 1999.

6. Lee JY, Hwang WI, and Lim ST: Antioxidant and anticancer activities of organic extracts from Platycodon grandiflorum A. De Candolle roots. J Ethnopharmacol 93, 409-415, 2004. doi: 10.1016/j.jep. 2004.04.017.
7. Chen CY, Cheng YB, Chen SY, Chien CT, Kuo YH, et al.: New bioactive clerodane diterpenoids from the roots of Casearia membranacea. Chem Biodivers 5, 162-167, 2008. doi: 10.1002/cbdv.200890007.

8. Rasul $\mathrm{A}$ and $\mathrm{Ma} \mathrm{T}$ : In vitro cytotoxic screening of 300 selected Chinese medicinal herbs against human gastric adenocarcinoma SGC-7901 cells. Afr J Pharm Pharmacol 6, 592-600, 2012.

9. Wu J, Wu Y, and Yang BB: Anticancer activity of Hemsleya amabilis extract. Life Sci 71, 2161-2170, 2002.

10. Aiyelaagbe OO, Hamid AA, Fattorusso E, Taglialatela-Scafati $\mathrm{O}$, Schröder $\mathrm{HC}$, et al.: Cytotoxic activity of crude extracts as well as of pure components from Jatropha species, plants used extensively in African traditional medicine. Evid Based Complement Altern Med 2011, 1-7, 2011.

11. Rasoanaivo P, Wright CW, Willcox ML, and Gilbert B: Whole plant extracts versus single compounds for the treatment of malaria: synergy and positive interactions. Malar J 10, 1-12, 2011. doi: 10.1186/ 1475-2875-10-S1-S4.

12. Yadav $\mathrm{R}$ and Agarwala $\mathrm{M}$ : Phytochemical analysis of some medicinal plants. J Phytol 3, 10-14, 2011.

13. Ma X, Zheng C, Han L, Xie B, Jia J, et al.: Synergistic therapeutic actions of herbal ingredients and their mechanisms from molecular interaction and network perspectives. Drug Discov Today 14, 579-588, 2009. doi:10.1016/j.drudis.2009.03.012

14. Zareisedehizadeh S, Tan $\mathrm{CH}$, and Koh HL: A review of botanical characteristics, traditional usage, chemical components, pharmacological activities, and safety of Pereskia bleo (Kunth) DC. Evid Based Complement Altern Med 2014, 1-11, 2014.

15. Tan M, Sulaiman S, Najimuddin N, Samian M, and Muhammad TT: Methanolic extract of Pereskia bleo (Kunth) DC. (Cactaceae) induces apoptosis in breast carcinoma, T47-D cell line. J Ethnopharmacol 96, 287-294, 2005.

16. Wahab S, Abdul A, Mohan S, Al-Zubain A, Elhassan $\mathrm{M}$, et al.: Biological activities of Pereskia bleo extracts. Int J Pharmacol 5, 71-75, 2009.

17. Butterworth CA and Wallace RS: Molecular phylogenetics of the leafy cactus genus Pereskia (Cactaceae). Syst Bot 30, 800-808, 2005.

18. Sharif K, Rahman M, Zaidul I, Jannatul A, Akanda $\mathrm{M}$, et al.: Pharmacological relevance of primitive leafy cactuses Pereskia. Res J Biotechnol 8, 134-142, 2013.

19. Er HM, Cheng EH, and Radhakrishnan AK: Anti-proliferative and mutagenic activities of aqueous and methanol extracts of leaves from Pereskia bleo (Kunth) DC (Cactaceae). J Ethnopharmacol 113, 448-456, 2007. doi: 10.1016/j.jep.2007.06.026.

20. Malek SN, Shin SK, Wahab NA, and Yaacob H: Cytotoxic components of Pereskia bleo (Kunth) DC. (Cactaceae) leaves. Molecules 14, 1713-1724, 2009. doi: 10.3390/molecules14051713.

21. Sim K, Sri Nurestri AM, Sinniah SK, Kim KH, and Norhanom AW: Acute oral toxicity of Pereskia bleo and Pereskia grandifolia in mice. Phog Mag 6, 67-70, 2010. doi: 10.4103/0973-1296.59969. 
22. Sri Nurestri A, Norhanom A, Hashim Y, Sim K, Hong S, et al.: Cytotoxic activity of Pereskia bleo (Cactaceae) against selected human cell lines. Int $J$ Cancer Res 4, 20-27, 2008.

23. Yen KP, Abdullah MSB, Syafri S, Raju SK, and Yahya $\mathrm{C}$ : A preliminary survey on the medicinal uses and effectiveness of Pereskia bleo used by people of three villages in the State of Kelantan, Malaysia. Int J Herb Med 1, 1-4, 2013.

24. Sim K, Sri Nurestri A, and Norhanom A: Phenolic content and antioxidant activity of crude and fractionated extracts of Pereskia bleo (Kunth) DC. (Cactaceae). Afr J Pharm Pharmaco 4, 193-201, 2010.

25. Wang SJ, Zheng CJ, Peng C, Zhang H, Jiang YP, et al.: Plants and cervical cancer: an overview. Expert Opin Invest Drugs 22, 1133-1156, 2013. doi: 10.1517/ 13543784.2013.811486.

26. Kuete V, Seo EJ, Krusche B, Oswald M, Wiench B, et al.: Cytotoxicity and pharmacogenomics of medicinal plants from traditional Korean medicine. Evid Based Complement Altern Med 2013, 1-14, 2013. doi: $10.1155 / 2013 / 341724$.

27. Srisawat T, Chumkaew P, Heed-Chim W, Sukpondma $\mathrm{Y}$, and Kanokwiroon K: Phytochemical screening and cytotoxicity of crude extracts of Vatica diospyroides Symington type LS. Trop J Pharm Res 12, 71-76, 2013.

28. Fatemeh $\mathrm{K}$ and Khosro P: In vitro cytotoxic activity of aqueous root extract of Althea kurdica against endothelial human bone marrow cells (line k562) and human lymphocytes. Bull Env Pharmacol Life Sci 2, 23-29, 2013.

29. Badmus JA, Ekpo OE, Hussein AA, Meyer M, and Hiss DC: Antiproliferative and apoptosis induction potential of the methanolic leaf extract of Holarrhena floribunda (G. Don). Evid Based Complement Altern Med 2015, 1-11, 2015. doi: 10.1155/2015/756482.

30. Abdul-Wahab I, Guilhon C, Fernandes P, and Boylan F: Anti-nociceptive activity of Pereskia bleo Kunth. (Cactaceae) leaves extracts. J Ethnopharmacol 144, 741-746, 2012. doi: 10.1016/j.jep.2012.10.029.

31. Endrini S, Rahmat A, Ismail P, and Taufiq-Yap Y: Cytotoxic effect of $\gamma$-sitosterol from Kejibeling (Strobilanthes crispus) and its mechanism of action towards c-myc gene expression and apoptotic pathway. Med J Indones 23, 203-208, 2015.

32. Sharma SH, Thulasingam $\mathrm{S}$, and Nagarajan $\mathrm{S}$ : Terpenoids as anti-colon cancer agents - a comprehensive review on its mechanistic perspectives. Eur J Pharmacol 795, 169-178, 2017.

33. Wiman KG and Zhivotovsky B: Understanding cell cycle and cell death regulation provides novel weapons against human diseases. J Intern Med 281, 483-495, 2017. doi: 10.1111/joim.12609.

34. Mantena SK, Sharma SD, and Katiyar SK: Berberine, a natural product, induces G1-phase cell cycle arrest and caspase-3-dependent apoptosis in human prostate carcinoma cells. Mol Cancer Ther 5, 296-308, 2006. doi: 10.1158/1535-7163.MCT-05-0448.

35. Chen J: The cell-cycle arrest and apoptotic functions of p53 in tumor initiation and progression. Cold Spring Harb Perspect Med 6, a026104, 2016. doi: 10. 1101/cshperspect.a026104.

36. Visconti R, Della Monica R, and Grieco D: Cell cycle checkpoint in cancer: a therapeutically targetable double-edged sword. J Exp Clin Cancer Res 35, 1-8, 2016. doi: 10.1186/s13046-016-0433-9.

37. Li LK, Rola AS, Kaid FA, Ali AM, and Alabsi AM: Goniothalamin induces cell cycle arrest and apoptosis in H400 human oral squamous cell carcinoma: a caspase-dependent mitochondrial-mediated pathway with downregulation of NF-kappabeta. Arch Oral Biol 64, 28-38, 2016. doi: 10.1016/j.archoralbio.2015.12.002.

38. Wang HY, Yu HZ, Huang SM, and Zheng YL: p53, $\mathrm{Bcl}-2$ and cox-2 are involved in berberine hydrochloride-induced apoptosis of HeLa229 cells. Mol Med Rep 14, 3855-3861, 2016. doi: 10.3892/mmr.2016.5696.

39. Giono LE and Manfredi JJ: Mdm2 is required for inhibition of Cdk2 activity by $\mathrm{p} 21$, thereby contributing to p53-dependent cell cycle arrest. Mol Cell Biol 27, 4166-4178, 2007.

40. Wu S, Liu B, Zhang Q, Liu J, Zhou W, et al.: Dihydromyricetin reduced Bcl-2 expression via p53 in human hepatoma HepG2 cells. PLoS One 8, 1-7, 2013. doi: 10.1371/journal.pone.0076886.

41. Amaral JD, Xavier JM, Steer CJ, and Rodrigues CM: The role of p53 in apoptosis. Discov Med 9, 145-152, 2010.

42. Kavitha N, Oon CE, Chen Y, Kanwar JR, and Sasidharan S: Phaleria macrocarpa (Boerl.) fruit induce G0/G1 and G2/M cell cycle arrest and apoptosis through mitochondria-mediated pathway in MDA-MB-231 human breast cancer cell. $J$ Ethnopharmacol 201, 42-55, 2017.

43. Ng KB, Bustamam A, Sukari MA, Abdelwahab SI, Mohan S, et al.: Induction of selective cytotoxicity and apoptosis in human T4-lymphoblastoid cell line (CEMss) by boesenbergin $\mathrm{A}$ isolated from Boesenbergia rotunda rhizomes involves mitochondrial pathway, activation of caspase 3 and G2/M phase cell cycle arrest. BMC Complement Altern Med 13, 1-15, 2013. doi: 10.1186/1472-6882-13-41. 